\title{
Semantically Marked English Subjects: Potential and Actual Areas of Difficulty from the Point of View of Hungarian Learners of English
}

\author{
Karolina Kalocsai \\ Department of English Language Teacher Education and Applied Linguistics \\ Institute of English and American Studies \\ University of Szeged, Hungry
}

Received: 20 April 2008 / Accepted: 22 November 2008

ISSN: $1697-7467$

\begin{abstract}
L2 learners of English often come across sentences such as Next month sees the president in town or The hospital treats people with a rare condition. These sentences are challenging because of the non-agentive semantic roles they take in their subject position. I have set the goal of the present paper to document how 65 Hungarian learners at various levels of English proficiency cope with a range of non-agentive roles; and whether the semantically marked subjects pose an area of difficulty for them. The present study has great potential because of its major pedagogical implications and the valuable insights it provides into the typological differences between English and Hungarian. Key words: non-agentive subjects, semantic roles, markedness, learner error, degree of difficulty.
\end{abstract}

Sujetos marcados semánticamente en inglés: áreas de dificultad potenciales y reales desde el punto de vista de los estudiantes húngaros de inglés

RESUMEN: El fin de este artículo es documentar como alumnos húngaros de inglés con distintos niveles se manejan con una gama de funciones no agentivas y si ésta les presenta dificultades. El estudio presenta importantes implicaciones pedagógicas y la introspección que proporciona en cuanto a las diferencias tipológicas entre inglés y húngaro. Palabras clave: Sujeto no agentivas, funciones semánticas, marcación, errores de alumnos, grado de dificultad.

\section{INTRODUCTION}

L2 learners of English often come across sentences such as Next month sees the president in town, The program discusses viewers' complaints or The hospital treats people with a rare condition. These sentences are challenging because of the non-agentive semantic roles they take in subject position. They are functionally and semantically more complex, less explicit, require more processing time, and have more cognitive cost (Callies 2006: 118) than sentences taking agentive roles. But what are non-agentive roles and what implications do 
they have for the L2 learners of English? I have set the goal of the present paper to explore whether (1) the non-agentive English roles are a potential area of difficulty for the Hungarian learners of English, and (2) a heterogeneous group of Hungarian learners of English face a problem when dealing with non-agentive English roles.

\section{THEORETICAL FRAMEWORK}

The notion of semantic roles is clearly tied to that of predicates. Predicates (usually, verbs) determine the number and kind of noun phrases that they can take as verbal arguments (Comrie 1989: 57) and impose semantic as well as syntactic restrictions on their argument(s). Semantic roles express the way in which the referent of a noun phrase argument «contributes to the state, action or situation described by the sentence» (Callies 2006: 112). They thus express relations between the noun phrase arguments and the predicates, rather than anything inherent in the noun phrases (Comrie 1989: 61). Instead of identifying the individual semantic roles, I will broadly distinguish between agentive and non-agentive roles, including the roles of Theme, Instrument, Location, Temporal, Cause and Force. The non-agentive semantic roles are known to occupy the lower end of the universal subject hierarchy (Saeed 1998: 146) and are regarded as more marked than agentive roles.

Mapping the semantic roles to syntactic functions reveals that despite the general tendency for Subjects to be Agents, for Direct Objects to be Themes and for Instruments to occur as Prepositional Phrases (Comrie 1989: 107, Saeed 1998: 144), there is no one-to-one relationship between semantic roles and grammatical relations. This is further complicated by the fact that different languages allow different semantic roles to surface in different syntactic positions (Callies 2006: 111). As an example, in a cross-linguistic perspective, English allows an unusually broad, while German quite a narrow range of different non-agentive semantic roles to surface as subject (Comrie 1989: 75, 79). This has especially great implications for L2 learners. Are the highly marked non-agentive English subjects a potential area of difficulty for the German learners of English? And how about the Hungarian learners of English? Do such arguments pose a challenge for them?

An alternative approach to answering the above questions is what has been called the Markedness Differential Hypothesis (Eckman 1977: 178-179). The hypothesis combines the contrastive analysis of languages with the concept of typological markedness and views those L2 structures as potentially difficult which are both different from and more marked than the equivalent L1 structures. The hypothesis has been successfully applied to answer the first question regarding the difficulties German learners of English are expected to face (Callies 2006). However, the second question concerning the difficulties of the Hungarian learners of English remains open.

The aim of the present study is threefold. On the one hand, it seeks to explore whether the non-agentive English subjects are a potential area of difficulty for the Hungarian learners of English; on the other hand, it attempts to investigate whether the non-agentive English subjects are an actual problem for Hungarian learners of English. Finally, it aims to test predictions. The study draws primarily on Callies (2006) but also expands on it in at least one very important respect: it does not only make predictions based on the Markedness Differential Hypothesis but also based on differences in frequency between the various groups of participants. The research questions are answered in three steps based on data collected 
from three groups of speakers: the predictions are formulated based on data collected from a group of native English speakers and a group of native Hungarian speakers; the real areas of difficulty are identified based on data collected from a mixed group of Hungarian learners of English; and finally, the predictions are checked on the basis of data collected from the group of Hungarian learners of English and the group of native English speakers.

\section{Methodology}

\subsection{Sample}

The data were collected from two native speaker groups and a group of L2 learners (see Table 1). The number of native Hungarian and of native English speakers was 35 each, thus making the total of the two native speaker groups 70 . The groups were heterogeneous in terms of the participants' age and level of education. While all the native Hungarian speakers were met in person, the majority of the native English speakers received the questionnaire through a «friend of a friend» via e-mail. The group of the L2 speakers consisted of 65 Hungarian learners of English - namely, secondary schools students, undergraduate students of English language and literature, and professional and trainee translators. Their numbers were 20, 31 and 14, respectively. While all the participants were fairly proficient learners of English, they had different levels of experience with the target language. This was purposeful so as to have a mixed group of learners. Students were handed the questionnaire by their teachers. However, the completion of the test was voluntary.

Table 1: The groups of participants $(n=135)$.

\begin{tabular}{|c|c|c|c|c|}
\hline \multicolumn{2}{|c|}{$\begin{array}{c}\text { Native speakers } \\
(\mathrm{n}=70)\end{array}$} & \multicolumn{3}{c|}{ Hungarian learners of English $(\mathrm{n}=65)$} \\
\hline $\begin{array}{c}\text { Native Hungarian } \\
\text { speakers }\end{array}$ & $\begin{array}{c}\text { Native English } \\
\text { speakers }\end{array}$ & $\begin{array}{c}\text { Secondary } \\
\text { school } \\
\text { students }\end{array}$ & $\begin{array}{c}\text { University } \\
\text { students }\end{array}$ & $\begin{array}{c}\text { Translators } \\
\text { and translator } \\
\text { trainees }\end{array}$ \\
\hline 35 & 35 & 20 & 31 & 14 \\
\hline
\end{tabular}

\subsection{Research Design}

The data elicitation had two main stages. First, the two native speaker groups were assigned an elicitation test (András 1980: 467), each in their L1 (see Appendices 1 and 2, respectively). The English elicitation test was designed first; the Hungarian elicitation test is a translated and slightly modified version of the English test. The tests consist of a sentence completion task and a grammaticality judgment task. In the former, the participants were exposed to 13 sentences in which the subjects were missing. The sentences allowed both an agentive and a non-agentive role in the subject position. The participants' task was to provide a subject for each of the sentences. In the second task, the participants were exposed to 13 pairs of sentences. The two sentences within each pair were paraphrases, the difference being 
that one of them was subject-marked, the other subject-unmarked. The order of the marked and unmarked sentences varied across the sentences. The participants were expected to judge whether only sentence (a), only sentence (b), both sentences (a) and (b), or neither sentence (a) nor (b) felt natural to them.

In the second stage of the data collection, the L2 learners "with the exception of the secondary school students « received the English elicitation test with an extra translation task (see Appendices 1 and 3). The secondary school students were exempted from the translation task because of the complexity of the translation process. The translation task itself contained 15 subject-marked sentences. The participants were asked to provide a translation for each of the sentences. They were given no guidelines on how to deal with the marked subjects.

The choice of the test items was governed by two criteria. On the one hand, an attempt was made to have a variety of non-agentive roles in the subject position. Thus, the sentences provided in the grammaticality judgment task as well as those in the translation task take as many as five different non-agentive roles - namely, the roles of Location, Temporal, Force, Source and Instrument. The different roles, however, do not occur with the same frequency within the same task: some roles (e.g. that of Location) are better represented than the others. On the other hand, it was desirable that the test items are authentic or, at least, semiauthentic. Thus, the sentences used were taken from Callies's (2006) study and from online sources, mainly from BBC NEWS (http://news.bbc.co.uk/).

The ordering of the tasks is crucial. Some of the sentences in the acceptability judgment task recur in the translation task. To ensure that the translated sentences do not influence the acceptability judgments of the very same sentences, the acceptability judgment task had necessarily to precede the translation task. Furthermore, to prevent that exposure to the subjectmarked sentences in the acceptability judgment task in any way modifies the written production of subjects, the sentence completion task had necessarily to come first. Consequently, the best ordering of the tasks was deemed as follows: the sentence completion task came first, the acceptability judgment task second, and the translation task third. The participants received the tasks on separate sheets of paper and were warned not to diverge from the suggested order of tasks.

The three tasks measure different things and complement each other. A fundamental claim made in connection with the acceptability judgment task is that it does not allow conclusions about performance on other tasks. As, for instance, Schütze (1991: 61, cited in Kontra 2003: 231) emphasizes, the fact that a speaker judges a structure correct does not necessarily mean that they can use the same structure productively, either in speech or in writing. Data about the participants' language production in the present study will thus come from the sentence completion task, rather than from the acceptability judgment task. But then what exactly does the acceptability judgment task measure?

The question is best answered in the light of relatively recent findings (Hall 2006: 228). The task requires the participants to make judgments using their intuitions. Intuitions reflect the mental representation of the participants' linguistic knowledge (Kiss-Gulyás 2004: 56). Since, however, language knowledge develops in «culturally-framed and discursively patterned communicative activities» (Hall 2006: 228), intuitions also reflect speakers' experiences with the language. Frisch et al. (2001, cited in Hall et al. 2006: 228) provide an excellent example of the effect of frequency and diversity of exposure on intuitions. Speakers with a greater frequency and diversity of language experiences are more likely to have robust memory representations of low-probability words than those with less frequency and diversity of 
exposure. These findings explain why native speakers, too, rather than L2 learners alone show variation in their grammaticality judgments (see, for instance, Coppieters 1987 cited in KissGulyás 2004: 56). These findings have clear implications for the present study which elicited native speaker as well as L2 learner judgments.

\section{Results AND Discussion}

First, the findings of the elicitation tests are presented. The data obtained from the native English speakers are matched against those of the native Hungarian speakers. The analysis begins with the acceptability judgment task and continues with the sentence completion task. Separate areas of difficulty are predicted based on the Markedness Differential Hypothesis on the one hand and on differences in the frequency of use on the other. In the acceptability judgment task those subject-marked sentences qualify for potential areas of difficulty which are accepted by (1) one of the two groups only; or by (2) both of the groups but with significant difference in their choices. In the sentence completion task, those sentences are believed to indicate potential areas of difficulty in which (1) one group provides a marked role, whereas the other group provides an unmarked role; (2) one group provides a greater variety of marked roles than does the other; and (3) one group has significantly greater preference for marked roles in a given sentence than the other. Differences in frequency are calculated with the application of the Chi-square test. Those sentences are regarded as potentially difficult which show significant results at one of three levels: (a) $p<.05$, (b) $p<.01$ and (c) $\mathrm{p}<.001$. In cases where one or two cells have the expected count of less than 5 , the term «nonapplicable» is used.

In the second stage, the L2 learners are investigated against the backdrop of native English speakers. First, based on differences in frequency, the real areas of difficulty are identified. Specifically, in the judgment task, those areas of the target language are regarded as problematic where the L2 learners show significantly lower acceptability rates for subjectmarked sentences than do the native speakers; in the sentence completion task, those areas of the target language are considered problematic where the L2 learners produce significantly fewer subject-marked sentences than do the native speakers. Second, it is investigated whether the predictions are correct, in other words, whether the real areas of difficulty overlap with the potential areas of difficulty. Finally, it is shown whether the translation of the subjectmarked sentences is a problem for the highly proficient learners of English. The application of a variety of translation strategies, unidiomatic and wrong translations as well as no attempt to translate all serve as indicators of an area of difficulty.

\subsection{Native speakers: Acceptability judgments}

The very first finding of the acceptability judgment task is that, based on the Hypothesis, no prediction can be made about areas of difficulty. As can be seen in Table 2, there is not a single subject-marked sentence which is accepted by one of the groups and is rejected by the other. All the marked sentences are accepted by at least some participants in both groups.

Considering differences in frequency is a more efficient way for identifying potential areas of difficulty. Table 2 clearly shows that overall the English speakers judge more marked sentences natural than do the Hungarian speakers. A sentence-by-sentence analysis reveals that in 12 out of 13 test items, the number of speakers accepting the marked sentence is 
higher in the English group than in the Hungarian group. The difference is significant in 8 out of 9 sentences where the test is applicable. What this implies is that from the point of view of the Hungarian learners of English, the acceptability judgment task has 8 potentially difficult sentences - namely, sentences $1,2,3,5,6,8,9$ and 10 .

Table 2: Acceptability judgments made in connection with a range of subject-marked sentences by two groups of native speakers $(n=70)^{1}$.

\begin{tabular}{|c|c|c|c|c|c|c|}
\hline & & \multicolumn{2}{|c|}{ Native English } & \multicolumn{2}{c|}{ Native Hungarian } & \\
\hline Sentence & Role & $\begin{array}{c}\text { Accepts } \\
\text { marked }\end{array}$ & $\begin{array}{c}\text { Rejects } \\
\text { marked }\end{array}$ & $\begin{array}{c}\text { Accepts } \\
\text { marked }\end{array}$ & $\begin{array}{c}\text { Rejects } \\
\text { marked }\end{array}$ & $\chi^{\mathbf{2}}$ \\
\hline $\mathbf{1}$ & Location & 30 & 5 & 16 & 19 & $12.428^{\text {c }}$ \\
\hline $\mathbf{2}$ & Location & 32 & 3 & 24 & 11 & $5.714^{\text {a }}$ \\
\hline $\mathbf{3}$ & Instrument & 25 & 10 & 3 & 32 & $28.810^{\text {c }}$ \\
\hline $\mathbf{4}$ & Force & 33 & 2 & 34 & 1 & n.a. \\
\hline $\mathbf{5}$ & Instrument & 33 & 2 & 16 & 19 & $19.660^{\text {c }}$ \\
\hline $\mathbf{6}$ & Cause & 16 & 19 & 1 & 34 & $17.481^{\text {c }}$ \\
\hline $\mathbf{7}$ & Temporal & 9 & 25 & 1 & 34 & n.a. \\
\hline $\mathbf{8}$ & Location & 20 & 15 & 10 & 25 & $5.833^{\text {a }}$ \\
\hline $\mathbf{9}$ & Temporal & 32 & 3 & 15 & 20 & $18.714^{\text {c }}$ \\
\hline $\mathbf{1 0}$ & Cause & 24 & 11 & 2 & 32 & $28.863^{\text {c }}$ \\
\hline $\mathbf{1 1}$ & Location & 25 & 10 & 28 & 7 & n.s. \\
\hline $\mathbf{1 2}$ & Location & 34 & 1 & 32 & 3 & n.a. \\
\hline $\mathbf{1 3}$ & Location & 34 & 1 & 31 & 4 & n.a. \\
\hline
\end{tabular}

Table 2 also provides the opportunity for examining which particular non-agentive roles are potentially difficult. The sentences identified as problematic include 3 instances of the role of Location, 2 instances of the role of Instrument, another 2 instances of the role of Cause, and one instance of the role of Temporal. Although the present study is not concerned with predicting degrees of difficulty, the data at hand implies that the roles examined are not equally difficult for speakers. It might be that the roles of Instrument and Cause are potentially more problematic than the roles of Location and Temporal. The underlying hypothesis behind this claim - in fact, a speculation - is that roles which elicit statistically significant results every time they make an appearance are potentially more difficult than those which lead to statistically significant results occasionally only. In particular, the roles of Instrument and Cause surface in two sentences and elicit statistically significant results in both cases. In contrast, the role of Location leads to statistically significant results in 3 out of 6 cases, and the role of Temporal in 1 out of 2 cases. As was claimed above, at present this is nothing more than a speculation in need of further testing. A final point to be made here has to do with the role of Force. Although it is tested with one single item based on which no solid conclusions can be drawn, it is not a likely candidate for an area of difficulty: it is better accepted by the Hungarian speakers than by the English speakers.

1. ${ }^{\mathrm{a}} \mathrm{p}<0.05 .{ }^{\mathrm{b}} \mathrm{p}<0.01 .{ }^{\mathrm{c}} \mathrm{p}<0.001$. n.s. $=$ not significant at the $\mathrm{p}<0.05$ level. n.a. $=$ non-applicable. 


\subsection{Native speakers: Sentence completion task}

In the sentence completion task the application of the Hypothesis leads to valuable data. As a reminder, in this particular task those sentences are regarded as potential areas of difficulty in which (1) the English group provides a marked role while the Hungarian group provides an unmarked role, or (2) the English group provides a greater variety of marked roles than does the Hungarian group. As can be seen in Table 3, several sentences meet one of the above criteria. Sentence 2 qualifies as a potential area of difficulty based on criterion 1, while Sentences 1, 3, 7, 10 and 11 qualify as potential areas of difficulty based on criterion 2 .

Table 3: Sentence completion task: semantically marked subjects produced by native English and native Hungarian speakers $(n=70)$.

\begin{tabular}{|c|c|c|}
\hline Sentence & Native English & Native Hungarian \\
\hline 1 & $\begin{array}{l}\text { France (Location) } \\
\text { A good grape (Theme) } \\
\text { Hard work (Instrument) }\end{array}$ & Villány (Location) \\
\hline 2 & A hefty bribe (Instrument) & - \\
\hline 3 & $\begin{array}{l}\text { The explosion (Cause) } \\
\text { The fog (Force) }\end{array}$ & The shots (Cause) \\
\hline 4 & $\begin{array}{l}\text { Vital repairs (Cause) } \\
\text { Heavy fog (Force) }\end{array}$ & $\begin{array}{l}\text { The strict passport control (Cause) } \\
\text { Bad weather (Force) }\end{array}$ \\
\hline 5 & The forum (Location) & The university papers (Location) \\
\hline 6 & The sponsored walk (Instrument) & The concert (Instrument) \\
\hline 7 & $\begin{array}{l}\text { The emergency room (Location) } \\
\text { A special programme (Instrument) }\end{array}$ & The local hospital (Location) \\
\hline 8 & The mudslide (Force) & $\begin{array}{l}\text { The floods (Force) } \\
\text { The explosion (Cause) }\end{array}$ \\
\hline 9 & The tent (Location) & The dormitory room (Location) \\
\hline 10 & $\begin{array}{l}\text { Austria (Location) } \\
2005 \text { (Temporal) }\end{array}$ & Vienna (Location) \\
\hline 11 & $\begin{array}{l}\text { Freezing fog (Force) } \\
\text { Bomb scare (Cause) }\end{array}$ & The snowdrift (Force) \\
\hline 12 & $\begin{array}{l}\text { The newsreport (Location) } \\
\text { The poll (Instrument) }\end{array}$ & $\begin{array}{l}\text { The office (Location) } \\
\text { The survey (Instrument) }\end{array}$ \\
\hline 13 & $\begin{array}{l}\text { Ethnic cleansing (Cause) } \\
\text { A heat wave (Force) }\end{array}$ & $\begin{array}{l}\text { The bomb attack (Cause) } \\
\text { The earthquake (Force) }\end{array}$ \\
\hline
\end{tabular}


Differences in frequency also point to several areas of difficulty. As Table 4 illustrates, the English speakers produce significantly more non-agentive subjects in 6 sentences. The 6 sentences and thus the 6 potential areas of difficulty are as follows: sentences $1,3,5,9,11$ and 12. It is striking that 3 of the 6 areas overlap with some of those areas of difficulty which have been identified above based on the criteria of the Hypothesis. This raises the important question to what extent the various types of roles within a sentence contribute to the statistical findings. Would, for instance, sentence 1 show statistically significant results if the roles of Theme and Instrument \% the two roles missing from the parallel Hungarian sentences \% were excluded from the statistical calculations? Obviously, to answer these questions we would need to know what the proportion of the various types of roles within a sentence is. Since, however, the data presented in Table 4 does not allow for such a detailed analysis, these questions could only be investigated in future research. Let us now turn to the more interesting task of checking whether our predictions are correct.

Table 4: Semantically marked and unmarked subjects provided by two groups of native speakers $(n=70)^{2}$.

\begin{tabular}{|c|c|c|c|c|c|c|}
\hline & & $\begin{array}{l}\text { Native } \\
\text { English }\end{array}$ & $\begin{array}{c}\text { Native } \\
\text { Hungarian }\end{array}$ & & & \\
\hline Sentence & Role & $\begin{array}{c}\text { Uses } \\
\text { marked }\end{array}$ & $\begin{array}{c}\text { Uses } \\
\text { unmarked }\end{array}$ & $\begin{array}{c}\text { Uses } \\
\text { marked }\end{array}$ & $\begin{array}{c}\text { Uses } \\
\text { unmarked }\end{array}$ & $\chi^{2}$ \\
\hline 1 & $\begin{array}{l}\text { Loc/Theme/ } \\
\text { Inst }\end{array}$ & 28 & 7 & 17 & 18 & $7.529^{\mathrm{b}}$ \\
\hline 2 & Instrument & 1 & 32 & - & 35 & n.a. \\
\hline 3 & Cause/Force & 23 & 12 & 4 & 31 & $21.766^{\mathrm{c}}$ \\
\hline 4 & Cause/Force & 29 & 6 & 22 & 12 & n.s. \\
\hline 5 & Location & 15 & 18 & 1 & 34 & $17.129^{\mathrm{c}}$ \\
\hline 6 & Instrument & 7 & 28 & 5 & 30 & n.s. \\
\hline 7 & Loc/Inst & 8 & 27 & 17 & 17 & $5.499^{\mathrm{a}}$ \\
\hline 8 & Cause/Force & 33 & 1 & 27 & 8 & n.a. \\
\hline 9 & Location & 34 & 1 & 25 & 10 & $8.737^{\mathrm{b}}$ \\
\hline 10 & Loc/Temp & 20 & 15 & 20 & 15 & n.s. \\
\hline 11 & Cause/Force & 14 & 19 & 1 & 34 & $15.467^{\mathrm{c}}$ \\
\hline 12 & Loc/Inst & 28 & 7 & 13 & 22 & $13.246^{\mathrm{c}}$ \\
\hline 13 & Cause/Force & 35 & - & 31 & 4 & n.a. \\
\hline
\end{tabular}

2. Note: ${ }^{\mathrm{a}} \mathrm{p}<0.05 .{ }^{\mathrm{b}} \mathrm{p}<0.01 .{ }^{\mathrm{c}} \mathrm{p}<0.001$. n.s. $=$ not significant at the $\mathrm{p}<0.05$ level. . $\mathrm{a} .=$ non-applicable. Loc $=$ Location, Inst $=$ Instrument, Temp $=$ Temporal 


\subsection{L2 learners of English: Acceptability judgment task}

To check predictions, we first need to identify the real problems the Hungarian learners of English face when dealing with subject-marked sentences. As a reminder, those sentences are considered to be a real problem which elicit statistically different results from the group of the L2 learners and that of the native English speakers. Based on results summarized in Table 5, there emerge 8 sentences in which the L2 learners show significantly lower acceptability rates for the subject-marked sentences than the native speakers. The 8 sentences, namely, sentences $1,2,3,6,9,10,12$ and 13, thus indicate real areas of difficulty. It is noteworthy that 4 of them take the role of Location in subject position, 2 of them that of Cause, one that of Instrument, and another one that of Temporal. This means that out of the 5 analyzed nonagentive roles, 4 pose a real challenge for the L2 learners. As far as the rest of the sentences are concerned, in 3 of them the Chi-square test is not applicable, and in 2 of them the performance of the two groups does not significantly differ.

Table 5: Acceptability judgments made in connection with a range of subject-marked sentences by a mixed group of Hungarian learners of English and a group of native English speakers $(n=100)^{3}$.

\begin{tabular}{|c|c|c|c|c|c|c|}
\hline & & \multicolumn{2}{|c|}{ Native English } & \multicolumn{2}{c|}{ L2 learners } & \\
\hline Sentence & Role & $\begin{array}{c}\text { Accepts } \\
\text { marked }\end{array}$ & $\begin{array}{c}\text { Rejects } \\
\text { marked }\end{array}$ & $\begin{array}{c}\text { Accepts } \\
\text { marked }\end{array}$ & $\begin{array}{c}\text { Rejects } \\
\text { marked }\end{array}$ & $\chi^{\mathbf{2}}$ \\
\hline $\mathbf{1}$ & Location & 30 & 5 & 37 & 28 & $8.529^{\text {b }}$ \\
\hline $\mathbf{2}$ & Location & 32 & 3 & 43 & 22 & $7.751^{\text {b }}$ \\
\hline $\mathbf{3}$ & Instrument & 25 & 10 & 29 & 36 & $6.585^{\text {a }}$ \\
\hline $\mathbf{4}$ & Force & 33 & 2 & 54 & 11 & n.a. \\
\hline $\mathbf{5}$ & Instrument & 33 & 2 & 58 & 7 & n.a. \\
\hline $\mathbf{6}$ & Cause & 16 & 19 & 11 & 54 & $9.568 \mathrm{~b}$ \\
\hline $\mathbf{7}$ & Temporal & 9 & 25 & 9 & 56 & n.s. \\
\hline $\mathbf{8}$ & Location & 20 & 15 & 33 & 32 & n.s. \\
\hline $\mathbf{9}$ & Temporal & 32 & 3 & 41 & 23 & $8.750^{\text {b }}$ \\
\hline $\mathbf{1 0}$ & Cause & 24 & 11 & 29 & 35 & $4.921 \mathrm{a}$ \\
\hline $\mathbf{1 1}$ & Location & 25 & 10 & 49 & 16 & n.s. \\
\hline $\mathbf{1 2}$ & Location & 34 & 1 & 48 & 17 & $8.365^{\text {b }}$ \\
\hline $\mathbf{1 3}$ & Location & 34 & 1 & 22 & 43 & $36.992^{\mathrm{c}}$ \\
\hline
\end{tabular}

3. Note: ${ }^{a} p<0.05 .{ }^{b} p<0.01 .{ }^{c} p<0.001$. n.s. $=$ not significant at the $p<0.05$ level. n.a. $=$ non-applicable. 
The matching of the potential areas of difficulty against the real areas of difficulty shows that out of the 8 predicted problems 6 are indeed a problem. Specifically, the potential and the real areas of difficulty overlap in sentences 1,2, 3, 6, 9 and 10. Having said this, there emerges a new and even more challenging task, namely, how to account for the four sentences where the potential and the real areas of difficulty do not overlap. Sentences 5 and 8 were expected to be a problem, however, when evaluating them, the L2 learners make judgments similar to those of the native speakers of English. Sentence 5, in particular, ends up being accepted by the vast majority of the participants in both groups; sentence 8 ends up being evaluated as natural by about half of both groups. This suggests that the Hungarian learners of English are quite familiar with the verbs raise and treat and the types of noun phrase arguments they may take. Sentences 12 and 13 have challenged the L2 learners when, in fact, they were not expected to. I suggest there are different reasons for this finding. Sentence 12 could have been rejected simply because of it being shorter and seemingly less complex than the rest of the evaluated sentences. The problem with sentence 13 is perhaps not so much that it has proved to be an area of difficulty, rather that the difficulty was not predicted correctly. It is likely that the Hungarian equivalent of the English sentence was not adequately chosen and did not prove an efficient tool for predicting an area of difficulty.

\subsection{L2 learners of English: Sentence completion task}

Again, checking the predictions necessarily begins with identifying real areas of difficulty. First, let us examine what real areas of difficulty we can identify in line with the Hypothesis. As Table 6 demonstrates, the L2 learners produce semantically marked subjects in every sentence - or in almost every one of them. Sentence 2 may very well be an exception: the participants who fill it in with a non-agentive subject end up with a sentence similar to sentence 3 of the translation task. This might be the result of their doing the sentence completion task under the influence of the translation task. I therefore suggest considering sentence 2 as not taking marked roles and posing an area of difficulty. I further claim that sentences 1, 3, 7, 10 and 11 are an area of difficulty. The evidence comes from data presented in Table 5 which shows that in these particular sentences the L2 learners provide a smaller range of marked subjects than do the native English speakers.

By matching the above problematic sentences against the predictions, we soon realize that what we were expecting has proved correct. It is exactly those 6 sentences which were proposed to be difficult which have turned out to be difficult. In other words, the L2 learners avoid using (a variety of) marked roles in exactly the same sentences where the native Hungarian learners avoid using (a greater variety of) non-agentive roles. The implication is that the Hungarian learners of English, even when highly proficient in English, continue to use (a variety of) marked roles only where they would use (a variety of) marked roles as native speakers of Hungarian. 
Table 6: Sentence completion task: semantically marked subjects produced by native English speakers and Hungarian learners of English $(n=100)$.

\begin{tabular}{|c|c|c|}
\hline Sentence & Native English & Native Hungarian \\
\hline 1 & $\begin{array}{l}\text { France (Location) } \\
\text { A good grape (Theme) } \\
\text { Hard work (Instrument) }\end{array}$ & $\begin{array}{l}\text { This vineyard (Location) } \\
\text { Grape (Theme) }\end{array}$ \\
\hline 2 & A hefty bribe (Instrument) & 5 million dollars (Instrument) \\
\hline 3 & $\begin{array}{l}\text { The explosion (Cause) } \\
\text { The fog (Force) }\end{array}$ & The gun (Cause) \\
\hline 4 & $\begin{array}{l}\text { Vital repairs (Cause) } \\
\text { Heavy fog (Force) }\end{array}$ & $\begin{array}{l}\text { Strike (Cause) } \\
\text { Severe weather conditions (Force) }\end{array}$ \\
\hline 5 & The forum (Location) & The talk show (Location) \\
\hline 6 & The sponsored walk (Instrument) & The concert (Instrument) \\
\hline 7 & $\begin{array}{l}\text { The emergency room (Location) } \\
\text { A special programme (Instrument) }\end{array}$ & A hospital (Location) \\
\hline 8 & The mudslide (Force) & The flood (Force) \\
\hline 9 & The tent (Location) & The caravan (Location) \\
\hline 10 & $\begin{array}{l}\text { Austria (Location) } \\
2005 \text { (Temporal) }\end{array}$ & Vienna (Location) \\
\hline 11 & $\begin{array}{l}\text { Freezing fog (Force) } \\
\text { Bomb scare (Cause) }\end{array}$ & Big storm (Force) \\
\hline 12 & $\begin{array}{l}\text { The newsreport (Location) } \\
\text { The poll (Instrument) }\end{array}$ & $\begin{array}{l}\text { This article (Location) } \\
\text { The poll (Instrument) }\end{array}$ \\
\hline 13 & $\begin{array}{l}\text { Ethnic cleansing (Cause) } \\
\text { A heat wave (Force) }\end{array}$ & $\begin{array}{l}\text { The war (Cause) } \\
\text { The tsunami (Force) }\end{array}$ \\
\hline
\end{tabular}

Second, from the point of view of differences in frequency, those areas of the target language are considered to be a challenge where the L2 learners produce significantly fewer subject-marked sentences than do the native English speakers. As can be seen in Table 7, this is exactly the case in 7 of the 13 sentences \% namely, in sentences $1,3,4,9,11,12$ and 13 . As far as the remaining 6 sentences are concerned, in 2 of them the test has failed to apply, and in 4 of them it has led to not significant results. Again, it would be useful to see what the proportion of the various types of roles in a given sentence is and how the various types of roles contribute to the statistical findings observed. These questions, however, cannot be answered based on the present data. 
Table 7: Semantically marked and unmarked subjects provided by a mixed group of Hungarian learners of English and a group of native English speakers $(n=100)^{4}$.

\begin{tabular}{|c|c|c|c|c|c|c|}
\hline \multirow{2}{*}{ Sentence } & Role & \multicolumn{2}{|c|}{ Native English } & \multicolumn{2}{c|}{ L2 learners } & \\
\hline $\mathbf{1}$ & Loc/Theme/Inst & 28 & $\begin{array}{c}\text { Uses } \\
\text { marked }\end{array}$ & $\begin{array}{c}\text { Uses } \\
\text { marked }\end{array}$ & $\begin{array}{c}\text { Uses } \\
\text { unmarked }\end{array}$ & $\chi^{\mathbf{2}}$ \\
\hline $\mathbf{2}$ & Instrument & 1 & 32 & 36 & 27 & $5.188^{\text {a }}$ \\
\hline $\mathbf{3}$ & Cause/Force & 23 & 12 & 25 & 36 & n.a. \\
\hline $\mathbf{4}$ & Cause/Force & 29 & 6 & 25 & 30 & $12.468^{\text {c }}$ \\
\hline $\mathbf{5}$ & Location & 15 & 18 & 23 & 39 & n.s. \\
\hline $\mathbf{6}$ & Instrument & 7 & 28 & 9 & 52 & n.s. \\
\hline $\mathbf{7}$ & Loc/Inst & 8 & 27 & 15 & 45 & n.s. \\
\hline $\mathbf{8}$ & Cause/Force & 33 & 1 & 60 & 4 & $?$ \\
\hline $\mathbf{9}$ & Location & 34 & 1 & 26 & 12 & $10.268^{\text {b }}$ \\
\hline $\mathbf{1 0}$ & Loc/Temp & 20 & 15 & 36 & 25 & n.s. \\
\hline $\mathbf{1 1}$ & Cause/Force & 14 & 19 & 1 & 52 & $23.209^{\text {c }}$ \\
\hline $\mathbf{1 2}$ & Loc/Inst & 28 & 7 & 18 & 38 & $19.734^{\text {c }}$ \\
\hline $\mathbf{1 3}$ & Cause/Force & 35 & - & 37 & 17 & $13.620^{\text {c }}$ \\
\hline
\end{tabular}

The above areas of difficulty are necessarily matched against the predictions based on differences in frequency. What we find is that out of the 6 areas that were proposed to be problematic, 5 indeed pose a challenge. Specifically, the expected areas of difficulty and the real areas of difficulty overlap in sentences 1, 3, 9, 11 and 12. This list of sentences covers the whole range of non-agentive subjects analyzed, meaning that all of them are potential and real problems for the L2 learners. Before moving on to the next task, it is worth examining why there is no overlap in the rest of the sentences. Sentence 5 was predicted to be a challenge, but the data collected from the L2 learners has not proved the hypothesis. This may be the result of the fact that the L2 learners \% at least, those who have provided a marked role \% are aware of the non-agentive roles the verb discuss can take in subject position. Sentences 4 and 13 represent different cases. While they were not expected to challenge the L2 learners, they have challenged them nevertheless. Therefore, many of the L2 learners are not aware of the non-agentive roles that the English verbs delay and wipe out may take in subject position.

4. $\mathrm{ap}<0.05 . \mathrm{bp}<0.01 . \mathrm{cp}<0.001$. n.s. $=$ not significant at the $\mathrm{p}<0.05$ level. n.a. $=$ non-applicable.Loc $=$ Location, Inst $=$ Instrument, Temp $=$ Temporal 


\subsection{L2 learners of English: Translation task}

The best evidence for the subject-marked sentences posing a problem for the Hungarian learners of English comes from the translation task. The L2 learners \% that is, the highly proficient undergraduate students of English language and literature and the professional/ trainee translators of English \% employ as many as 4 strategies to cope with the difficulty of the non-agentive subjects. In line with Callies (2006), the various strategies are as follows: (i) subject retained, verb changed (see example 1b), (ii) subject changed, verb retained, often, though by no means always, realizing the subject noun phrase of the English sentence as a prepositional phrase/adjunct (see example 1c), (iii) subject changed and verb retained, often, though by no means always realizing the subject noun phrase of the English sentence as a prepositional phrase/adjunct (see example 1d), and finally (iv) subject retained, verb not changed (see examples 1e). The claim for the area of difficulty is further strengthened by the presence of wrong translations, unidiomatic translations and missing translations. I use the term wrong translations to refer to cases where the original sentence has been misinterpreted and unidiomatic translations for cases where the translation is not natural to the Hungarian language.

(1) (a) The program discusses viewers' complains.

(b) A mûsor a nézõk panaszait vizsgálja. «The program examines the viewers' complaints.»

(c) A mûsorban a nézõk panaszaival foglalkoznak. «In the program, they are dealing with the complaints of the viewers ${ }^{5} . »$

(d) A programban a nézõk panaszait vitatják meg. «In the program, they are discussing the viewers' complaints.»

(e) A mûsor a nézõk panaszaival foglalkozik. «The program deals with the complaints of the viewers.»

Table 8 provides an overall picture of the participants' performance in the translation task. All in all, they are exposed to 675 sentences. The various strategies are successfully employed for the translation of $549(81.3 \%)$ sentences. They are efficient to various degrees. The most widely used translation strategy is the one which requires the subject and the verb to be retained. The second most widely used strategy is the one which requires both the subject and the verb to be changed, often realizing the subject of the original sentence as a prepositional phrase/adjunct. The third most widely used strategy is the one which requires the subject to be changed and the verb to be retained, often realizing the subject of the original sentence as a prepositional phrase/adjunct. The least widely used strategy requires the subject to be retained and the verb to be changed.

The four strategies used are of two main types. They either require the retention of the subject or the change of the subject. Out of the 549 sentences where the translation strategies are successfully applied, the learners opt for a change of the subject in $279(50.8 \%)$ sentences

5. In this sentence, as well as in the following one, they is an indefinite 3rd person plural subject the functional equivalent of which is the passive in English. 
and choose to retain the subject in $270(49.2 \%)$ cases. This implies that the learners have an almost equal tendency to use the two main types of translation strategies. But is there a tendency for a particular role to be translated by a particular strategy?

Table 8: Strategies applied for the translation of English subject-marked sentences by a group of Hungarian learners of English $(n=45)^{6}$.

\begin{tabular}{|c|c|c|c|c|c|c|c|}
\hline $\begin{array}{l}\text { Strategy } \\
\text { used } \\
\text { Sentence } \\
\text { no. }\end{array}$ & $\begin{array}{l}\text { S retained, } \\
\text { V not } \\
\text { changed }\end{array}$ & $\begin{array}{l}\text { S changed, } \\
\text { V changed, } \\
\text { (former } S=P P \text { ) }\end{array}$ & $\begin{array}{l}\text { S changed, } \\
\text { V retained, } \\
\text { (former subject = } \\
\text { PP) }\end{array}$ & $\begin{array}{l}S \text { retained, } \\
V \text { changed }\end{array}$ & $\begin{array}{l}\text { Wrong } \\
\text { translation }\end{array}$ & $\begin{array}{l}\text { Unidiomatic } \\
\text { translation }\end{array}$ & $\begin{array}{l}\text { No } \\
\text { translation }\end{array}$ \\
\hline 1 & 35 & 4 & 5 & - & - & 1 & - \\
\hline 2 & 23 & 17 & 3 & 2 & - & - & - \\
\hline 3 & - & 10 & 18 & 5 & 8 & 1 & 3 \\
\hline 4 & 8 & 6 & 6 & 5 & 17 & - & 3 \\
\hline 5 & - & 41 & - & - & 4 & - & - \\
\hline 6 & 11 & 25 & 8 & - & - & 1 & - \\
\hline 7 & 32 & 6 & 1 & 3 & - & 2 & 1 \\
\hline 8 & - & 4 & 7 & 5 & 7 & 16 & 6 \\
\hline 9 & 21 & 2 & 8 & 7 & 5 & - & 2 \\
\hline 10 & 29 & 3 & - & 12 & - & - & 1 \\
\hline 11 & 44 & 1 & - & - & - & - & - \\
\hline 12 & 1 & 38 & - & - & 3 & - & 3 \\
\hline 13 & 15 & 4 & 5 & 9 & 3 & 1 & 8 \\
\hline 14 & 1 & 5 & 23 & 1 & 3 & 4 & 8 \\
\hline 15 & - & - & 29 & 1 & 1 & 7 & 7 \\
\hline Total & $\begin{array}{c}220 \\
(32,6 \%)\end{array}$ & $\begin{array}{c}166 \\
(24,6 \%)\end{array}$ & $\begin{array}{c}113 \\
(16,7 \%)\end{array}$ & $\begin{array}{c}50 \\
(7,4 \%)\end{array}$ & $\begin{array}{c}51 \\
(7,6 \%)\end{array}$ & $\begin{array}{c}33 \\
(4,9 \%)\end{array}$ & $\begin{array}{c}42 \\
(6,2 \%)\end{array}$ \\
\hline
\end{tabular}

In answering the above question, let us consider which of the two main types of the strategies the majority of the participants use to translate a given sentence. Based on data presented in Table 7, the picture is quite clear. When dealing with sentences taking the roles of Location and Force, the majority of the learners choose to retain the subject. However, when dealing with sentences taking the roles of Cause, Temporal and Instrument, the majority of the participants opt for a change of subject. These statements hold for all the 15 sentences without an exception.

6. The selected roles are as follows: 1=Location, 2=Location, 3=Instrument, 4=Location, 5=Temporal, 6=Temporal, $7=$ Location, $8=$ Instrument, 9=Location, 10=Force, 11=Force, 12=Temporal, 13=Force, 14=Cause, $15=$ Cause. $\mathrm{S}=$ subject, $\mathrm{V}=$ verb, $\mathrm{PP}=$ prepositional phrase. 
Last but not least, consideration must be given to the sentences where the observed strategies do not successfully apply. Out of the total 675 sentences, $51(7.6 \%)$ result in wrong translations, $33(4.9 \%)$ in unidiomatic translations and $42(6.2 \%)$ are not translated at all. If these instances of occurrence are examined in isolation, they may falsely hint that the learners do not have difficulty when providing a translation for the selected marked sentences. However, if the instances of occurrence of unidiomatic translations, wrong translations and no translation are all pulled together, the number of problematic sentences rises to $126(18.7 \%)$. This certainly has pedagogical implications. To help learners become more efficient in interpreting subject-marked sentences, they need to be made aware of them and trained in dealing with them.

\section{Conclusions}

I have set the goal of the present paper to explore whether (1) the non-agentive English roles are a potential area of difficulty for the Hungarian learners of English and (2) a heterogeneous group of Hungarian learners of English face a problem when dealing with non-agentive English roles. I have shown that both from the point of view of the Markedness Differential Hypothesis and differences in frequency, the non-agentive English roles are a potential and a real area of difficulty for the Hungarian learners of English. There remains no doubt that the subject-marked English sentences require greater attention in language classes.

Acknowledgment: I would like to thank Anna Fenyvesi for her valuable feedback on an earlier draft of this paper.

\section{REFERENCES}

András, L. T. (1980). «Spatial adjectives: An English-Hungarian contrastive study», in L. Dezsõ and W. Nemser (eds.), Studies in English and Hungarian Contrastive Linguistics. Budapest: Akadémiai Kiadó, 453-490.

Callies, M. (2006). "Why money can't buy you anything in German: A functional-typological approach to the mapping of semantic roles to syntactic functions in SLA», in J. Arabski (ed.), Cross-Linguistic Influences in the Second Language Lexicon. Clevendon: Multilingual Matters, 111-128.

Comrie, B. (1989). Language Universals and Linguistic Typlogy: Syntax and Morphology. Chicago: University of Chicago Press.

Coppieters, R. (1987). «Competence differences between native and near-native speakers», in Language, 63, 544"573.

Eckman, F. (1977). "Markedness and the Contrastive Analysis Hypothesis», in M. Kontra, and H. Thomas (eds.). 1991. Readings in Applied Linguistics for Teachers of English. József Attila Tudományegyetem, Bölcsészettudományi Kar, Kézirat javitott kiadása. Budapest: Tankönyvkiadó, 172-189.

Hall, J. K., Cheng, A. and Clarlson, M. T. (2006). «Reconceptualizing multicompetence as a theory of language knowledge», in Applied Linguistics, 27, 2: 220-240. 
Kiss-Gulyás, J. (2004). The Acquisition of English Restrictive Relative Clauses by Hungarian Learners of English. Budapest: Akadémiai Kiadó.

Kontra, M. (szerk.) (2003). Nyelv és társadalom a rendszerváltáskori Magyarországon [Language and Society at the Time of the Change of Regime in Hungary]. Budapest: Osiris Kiadó.

Saeed, J. (1998). Semantics. Oxford: Blackwell.

Schütze, C. T. (1996). The Empirical Base of Linguistics: Grammaticality Judgments and Linguistic Methodology. Chicago: University of Chicago Press. 


\section{Appendix 1}

\section{TEST}

Task 1. Fill in the gaps so that you make grammatically correct sentences.

You may use one or more words.

produces good wine.

bought the election.

injured five people.

delayed the take-off.

discusses the viewers' complaints.

raised 1,5 million pounds for charity causes.

treats the victims of the blast.

destroyed hundreds of homes.

sleeps five adults.

celebrated the $250^{\text {th }}$ anniversary of Mozart's birth.

shut the airport.

examines voter apathy.

wiped out the town.

Task 2. The task has two stages.

First, decide which of the two sentences is (more) natural to you: only a), only b), both a) and b), neither a), nor b). Underline the appropriate answer.

Second, return to the sentence which you have not judged natural. Underline the word(s) in it that have made you reject the sentence.

1a) California grows the best oranges.

1b) The best oranges are grown in California.

only a) only b) both a) and b) neither a), nor b)

2a) My study examines voter apathy.

2b) I examine voter apathy in my study.

only a) only b) both a) and b) neither a), nor b)

3a) 69 million dollars bought him the election.

3b) He bought the election with 69 million dollars.

only a) only b) both a) and b) neither a), nor b)

4a) Severe weather conditions delayed the take-off.

4b) The take-off was delayed by severe weather conditions.

only a) only b) both a) and b) neither a), nor b) 
5a) The carol concert raised more than 1,300 pounds for charity causes.

5b) 1300 pounds were raised for charity causes by the carol concert.

only a) only b) both a) and b) neither a), nor b)

6a) The embassy has been closed due to a bomb threat.

6b) A bomb threat has closed the embassy.

only a) only b) both a) and b) neither a), nor b)

7a) Last year celebrated the $250^{\text {th }}$ anniversary of Mozart's birth.

$7 \mathrm{~b})$ The $250^{\text {th }}$ anniversary of Mozart's birth was celebrated last year. only a) only b) both a) and b) neither a), nor b)

8a) The victims of the blast are treated in the hospital.

8 b) The hospital treats the victims of the blast. only a) only b) both a) and b) neither a), nor b)

9a) The $3^{\text {rd }}$ of October marks the anniversary of German reunification.

9b) The anniversary of German reunification is celebrated on the $3^{\text {rd }}$ of October. only a) only b) both a) and b) neither a), nor b)

10a) A bus crash in Austria has killed 5 people.

10b) 5 people were killed in a bus crash in Austria.

only a) only b) both a) and b) neither a), nor b)

11a) The article reviews the heatwave of summer 2006 .

11b) The heatwave of summer 2006 is reviewed in the article. only a) only b) both a) and b) neither a), nor b)

12a) The room is cold.

$12 b)$ It is cold in the room. only a) only b) both a) and b) neither a), nor b)

13a) The cottage sleeps five adults.

13b) Five adults can spend the night in the cottage.

only a) only b) both a) and b) neither a), nor b) 


\section{Appendix 2}

TESZTLAP

\section{1. feladat}

Egészítsd ki a mondatot úgy, hogy értelmes legyen. Használhatsz egy vagy több szót.

1

2 .

3.

4.

5 .

6.

7.

8.

9.

10.

11.

12.

13. jó borokat termel. megvette a választásokat. megsebesítettek öt embert. késleltette a felszállást. a hallgatók panaszait vizsgálja. másfél millió forintot gyûjtött jótékonysági célra. kezeli a robbanás áldozatait. otthonok százait tették tönkre. öt felnõttnek ad szállást. ünnepelte Mozart születésének 250. évfordulóját. lezárta a repteret. a szavazók érdektelenségét vizsgálja. megsemmisítette a várost.

\section{2. feladat}

A feladat két részbõl áll. Elõször, döntsd el, a mondatpár mondatai közül melyik a természetes(ebb): csak az a), csak a b), mindkettõ egyformán vagy egyik sem. Húzd alá a megfelelõ választ. Ezután, térj vissza arra a mondatra, amit nem ítéltél természetesnek, és húzd benne alá azt a szót vagy kifejezést, ami miatt szerinted a mondat nem természetes.

1a) Kalifornia termeli a legjobb narancsot.

1b) Kaliforniában termelik a legjobb narancsot. csak az a) csak a b) mindkettõ egyformán egyik sem

2a) A tanulmányom a szavazók érdektelenségét vizsgálja.

2b) A tanulmányban a szavazók érdektelenségét vizsgálom. csak az a) csak a b) mindkettõ egyformán egyik sem

3a) Néhány millió forint megvette neki a választást.

3b) Néhány millió forinttal megvette a választást. csak az a) csak a b) mindkettõ egyformán egyik sem

4a) A rossz idõjárás miatt késõbb szállt fel a gép.

4b) A rossz idõjárás késleltette a felszállást. csak az a) csak a b) mindkettõ egyformán egyik sem

5a) A karácsonyi koncert egy millió forintot gyûjtött a kórháznak.

5b) A karácsonyi koncert egy millió forintot hozott a kórháznak. csak az a) csak a b) mindkettõ egyformán egyik sem

6a) Bombafenyegetés miatt lezárták a repteret.

6b) Bombafenyegetés lezárta a repteret. csak az a) csak a b) mindkettõ egyformán egyik sem

7a) A múlt év ünnepelte Mozart születésének 250. évfordulóját.

7b) A múlt évben ünnepelték Mozart születésének 250. évfordulóját. csak az a) csak a b) mindkettõ egyformán egyik sem 
8a) A kórházban kezelik a tûz sérültjeit.

8b) A kórház kezeli a tûz sérültjeit. csak az a) csak a b) mindkettõ egyformán egyik sem

9a) Október 3-a jelöli a német újraegyesítés évfordulóját.

9b) Október 3-án ünneplik a német újraegyesítés évfordulóját. csak az a) csak a b) mindkettõ egyformán egyik sem

10a) Egy buszbaleset Ausztriában megölt öt utast.

10b) Egy buszbalesetben Ausztriában meghalt öt utas. csak az a) csak a b) mindkettõ egyformán egyik sem

11a) A cikk az elõzõ évi hõhullámot elemzi.

11b) A cikkben az elõzõ évi hõhullámot elemzik. csak az a) csak a b) mindkettõ egyformán egyik sem

12 a) A folyosó huzatos.

12b) A folyosón huzat van. csak az a) csak a b) mindkettõ egyformán egyik sem

13a) A kunyhó öt felnõttnek ad szállást.

13b) A kunyhóban öt felnõtt éjszakázhat. csak az a) csak a b) mindkettõ egyformán egyik sem

\section{Appendix 3}

Task 3. Translate the following sentences into Hungarian.

1. Australia is producing excellent, good value red wine.

2. The island is dry for most of the year.

3. 69 million dollars bought Michael Bloomberg the election as Mayor of New York.

4. The hospital treats people with a rare condition.

5. Next month sees the president in town.

6. Sunday was sunny with clear skies.

7. Next year Burma marks its $60^{\text {th }}$ anniversary of independence from Britain.

8. A Harley Davidson motorcycle has raised \$360, 200 for the victims of the September 11 attacks.

9. The programme discusses viewers' complaints.

10. Hurricane Katrina killed more than 1, 200 people when it hit in August 2005.

11. Tropical storms destroyed thousands of homes.

12. Next month sees the release of a new album.

13. Blizzard conditions delayed an attempt by three women to walk to both Poles.

14. Bacteria alert has shut Indonesia's embassy in Australia.

15. A coach crash has injured 39 elderly people traveling to a shrine. 